\title{
Isolation and Optimization of Culture Conditions of a Bioflocculant-Producing Fungi from Kombucha Tea SCOBY
}

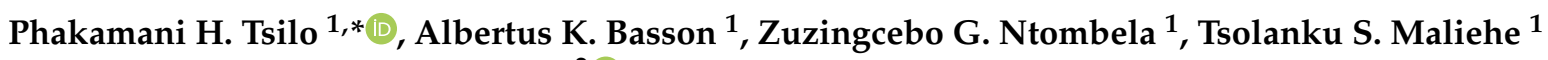 \\ and Rajasekhar V. S. R. Pullabhotla ${ }^{2}$ D \\ 1 Department of Biochemistry and Microbiology, Faculty of Science, Agriculture and Engineering, \\ University of Zululand, P/Bag X1001, KwaDlangezwa 3886, South Africa; BassonA@unizulu.ac.za (A.K.B.); \\ NtombelaZ@unizulu.ac.za (Z.G.N.); sidttmaliehe@gmail.com (T.S.M.) \\ 2 Department of Chemistry, Faculty of Science, Agriculture and Engineering, University of Zululand, P/Bag \\ X1001, KwaDlangezwa 3886, South Africa; pullabhotlav@unizulu.ac.za \\ * Correspondence: phakamanitsilo90@gmail.com; Tel.: +27-671-090-888
}

\section{check for}

updates

Citation: Tsilo, P.H.; Basson, A.K.; Ntombela, Z.G.; Maliehe, T.S.; Pullabhotla, R.V.S.R. Isolation and Optimization of Culture Conditions of a Bioflocculant-Producing Fungi from Kombucha Tea SCOBY. Microbiol. Res. 2021, 12, 950-966. https://doi.org/10.3390/ microbiolres 12040070

Academic Editor: Beniamino T. Cenci-Goga

Received: 25 October 2021 Accepted: 21 November 2021 Published: 14 December 2021

Publisher's Note: MDPI stays neutral with regard to jurisdictional claims in published maps and institutional affiliations.

Copyright: (c) 2021 by the authors. Licensee MDPI, Basel, Switzerland. This article is an open access article distributed under the terms and conditions of the Creative Commons Attribution (CC BY) license (https:// creativecommons.org/licenses/by/ $4.0 /)$.

\begin{abstract}
Biolocculants are gaining attention in research due to their environmental friendliness and innocuousness to human in comparison to the conventional flocculants. The present study aimed to investigate the ability of fungi from Kombucha tea SCOBY to produce effective bioflocculant in bulk. A $16 \mathrm{~S}$ rRNA gene sequence analysis was utilized to identify the isolate. The medium composition (carbon and nitrogen sources) and culture conditions (inoculum size, temperature, shaking speed, $\mathrm{pH}$, and time) were optimized using one-factor-at-a-time method. The functional groups, morphology, and crystallinity of the bioflocculant were evaluated using Fourier transform infrared (FT-IR), scan electron microscope (SEM) and X-ray diffractometry (XRD). The fungus was found to be Pichia kudriavzevii MH545928.1. It produced a bioflocculant with flocculating activity of 99.1\% under optimum conditions; $1 \%(v / v)$ inoculum size, glucose and peptone as nutrient sources, $35{ }^{\circ} \mathrm{C}, \mathrm{pH} 7$ and the shaking speed of $140 \mathrm{rpm}$ for $60 \mathrm{~h}$. A cumulus-like structure was revealed by SEM; FT-IR displayed the presence of hydroxyl, carboxyl, amine, and thiocynates. The XRD analysis demonstrated the bioflocculant to have big particles with diffraction peaks at $10^{\circ}$ and $40^{\circ}$ indicating its crystallinity. Based on the obtained results, P. kudriavzevii MH545928.1 has potential industrial applicability as a bioflocculant producer.
\end{abstract}

Keywords: bioflocculants; Pichia kudriavzevii; fungi; Kombucha tea SCOBY

\section{Introduction}

Flocculation is a purification technique whereby destabilized colloids in solution aggregate together through mechanisms such as charge neutralization and bridging [1]. Flocculants enhance agglomeration of colloidal particles in solution, consequently leading to easy separation [2]. Thus, flocculants are generally used in separation techniques, such as wastewater treatment, drinking water purification, activated sludge dehydration, food fermentation, and downstream processing [3]. They are typically categorized into two groups: chemical and natural flocculants-bioflocculants. Chemical flocculants are further divided into two group namely synthetic organic flocculants, e.g., polyethyleneimine and polyacrylamide byproducts and inorganic flocculants, which include aluminum sulfate and polyaluminum chloride [4]. Chemical flocculants are predominately employed because of their profound effectiveness [5]. However, they can cause harmful effects to humans as they are mutagenic, neurotoxic, and carcinogenic [6]. Moreover, due to their non-degradable nature, they tend to form large volume of sludge, consequently generating environmental pollution [7]. They tend to accumulate in water bodies where fish assimilate them. The assimilated polymers then interfere with fish gill function, causing high fish mortality; consequently leading to reduction in the supply of healthy fish for consumption [8]. Recently, 
the focus has shifted to the production of natural flocculants, also known as bioflocculants, due to their effectiveness and non-detrimental effects in comparison to chemical flocculants.

Bioflocculants are naturally occurring extracellular biopolymers that result from the exudation of plants and microorganisms including fungi, bacteria, algae, and yeast [9]. In contrast to chemical flocculants, bioflocculants are reported to be environmentally friendly as they are biodegradable and harmless to humans. Moreover, they do not cause any secondary pollution [3]. Louis Pasteur was the first to evaluate the potentiality of bioflocculants produced by the yeast Luvure casseeuse [10]. However, until now, there is a limited number of studies on fungal bioflocculants in comparison to bacterial bioflocculants reported [11]. Nevertheless, microorganisms turn to produce low bioflocculant yields. This has become one of the main constraints for their production and use industrially [12]. Thus, there is a constant search for novel bioflocculant producing strains with capability to produce high bioflocculant yield and enhanced activity [12].

Bioflocculant producing microorganisms have been isolated from a variety of sources, such as soil, palm mill effluents, activated sludge, etc. [13]. However, there are no reports on the isolation of these microorganisms from food such as Kombucha tea SCOBY (symbiotic culture of bacteria and yeast). Kombucha tea SCOBY is a fermented beverage that has recently attracted market attention. The consumption of this tea has expanded from China to all parts of the world due to its health-promoting benefits such as the ability to treat the digestive disorders, stimulate immune system, and possession of hypoglycemic and antiaging effects [14]. Moreover, Kombucha in tea is reported to improve the shelf-life of the tea [15]. The tea harbors symbiosis of acetic acid bacteria (AAB), lactic acid bacteria (LAB), and yeasts [16]. The bacteria and yeast numbers can reach $10^{6}$ colony forming units per milliliters $(\mathrm{CFU} / \mathrm{mL})$ in a culture which has been allowed to ferment for a period of 10 days. According to literature, the composition of yeast in the tea tends to outnumber the bacterial count [17]. These microorganisms assimilate different substrates in a tea as their carbon and nitrogen sources for their survival; consequently producing desired SCOBY products [18]. Thus, Kombucha tea is a potential reservoir for bioflocculant producing fungi.

The present study aimed at isolating and identifying a bioflocculant producing fungal strain from Kombucha tea SCOBY using conventional and 16S rRNA gene sequence analysis. The medium components and culture conditions of the isolate were optimized in order to improve yield and flocculating efficiency using the one-factor-at-a-time method. Finally, the extracted bioflocculant was characterized using scanning electron microscope (SEM) for evaluation of surface morphology, X-ray diffraction (XRD) for assessment of its crystallinity, and Fourier-transform infrared (FT-IR) for functional groups.

\section{Materials and Methods}

\subsection{Isolation of Bioflocculant-Producing Fungi}

The Kombucha tea with a SCOBY was purchased from Greenheart Organics Pinetown in Durban KwaZulu-Natal Province, delivered to the University of Zululand at KwaDlangezwa, in the province of KwaZulu-Natal in South Africa and used for bioflocculant production. Kombucha tea was prepared as follows: the tea (1/2 cup of sugar and two ordinary tea bags) was boiled with sterilized distilled water in a clean beaker $(1000 \mathrm{~mL})$ (ChemLabs, Johannesburg, South Africa). Afterwards, the tea was cooled, the starter culture (SCOBY) was then added. Lastly, the jar (ChemLabs, Johannesburg, South Africa) was covered with a few layers of a tightly woven cloth and wrapped with a rubber band for 5 days at room temperature. The tea was then serially diluted using sterile saline water $(0.85 \%)$ up to $10^{-5}$ dilution. For microbial isolation, potato dextrose agar (PDA) (Masiye Labs, Johannesburg, South Africa) was used. About $100 \mu \mathrm{L}$ of the diluted Kombucha tea broth was aseptically spread on agar plates (Reflecta Laboratory Supplies, Johannesburg, South Africa). Thereafter, the inoculated plates were incubated for 3 days at $37^{\circ} \mathrm{C}$ to obtain colonies. After the incubation period had elapsed, the colonies obtained were picked based on divergence in morphology, size, and color. The selected isolates were further 
sub-cultured on fresh agar plates to obtain pure cultures and re-incubated. Pure cultures were stored at $-80{ }^{\circ} \mathrm{C}$ in $50 \%$ glycerol (ChemLabs, Johannesburg, South Africa).

\subsection{Isolates Fermentation Activation}

A medium containing $10 \mathrm{~g}$ tryptone, $5 \mathrm{~g}$ sodium chloride, and $3 \mathrm{~g}$ beef extract (Reflecta Laboratory Supplies, Johannesburg, South Africa) was prepared in a liter of autoclaved distilled water. About $5 \mathrm{~mL}$ of the activation medium was transferred into dissimilar test tubes (Laboratory Consumables and Chemical Supplies Cc, Durban, South Africa) and autoclaved at $121^{\circ} \mathrm{C}$ for $15 \mathrm{~min}$. After autoclaving, the isolates were inoculated into the media and incubated for $24 \mathrm{~h}$ at $37^{\circ} \mathrm{C}$ with a rotary shaker (Laboratory Consumables and Chemical Supplies Cc, Durban, South Africa) at 160 rpm [19].

\subsection{Screening for Bioflocculant Production}

The method by Chen et al. [19] was followed for the bioflocculant production of the isolates. Production medium consisting of $20 \mathrm{~g}$ glucose, $0.5 \mathrm{~g}$ urea, $0.1 \mathrm{NaCl}, 0.3 \mathrm{~g}$ $\mathrm{NH}_{4} \mathrm{SO}_{4}, 0.3 \mathrm{~g} \mathrm{MgSO}_{4}, 5 \mathrm{~g} \mathrm{~K}_{2} \mathrm{HPSO}_{4}, 2 \mathrm{~g} \mathrm{KH}_{2} \mathrm{PSO}_{4}$, and $0.5 \mathrm{~g}$ yeast extract (ChemLabs, Johannesburg, South Africa) was prepared in a liter of Kombucha tea broth. Conical flasks $(250 \mathrm{~mL}$ ) (Laboratory Consumables and Chemical Supplies Cc, Durban, South Africa) were used to pour the production medium $(50 \mathrm{~mL})$ and then autoclaved. Thereafter, each flask was inoculated with pure isolates. All the inoculated flasks were incubated for 3 days at $30{ }^{\circ} \mathrm{C}$ with shaking speed of $160 \mathrm{rpm}$. After three days of incubation, $2 \mathrm{~mL}$ of the fermented medium was pipetted into sterile Eppendorf tubes (Labotec (Pty) Ltd., Cape Town, South Africa) and centrifuged (Labex Pty. Ltd., Johannesburg, South Africa) at $8000 \mathrm{rpm}$ for $15 \mathrm{~min}$. The supernatant was used to evaluate the ability of the isolates to produce a bioflocculant with excellent flocculating activity.

\subsection{Determination of the Flocculating Activity}

The method used by Luo et al. [20] was employed for the assessment of flocculating activity of the broth cultures. Briefly, kaolin solution (4 g/L) (Laboratory Consumables and Chemical Supplies Cc, Durban, South Africa) was prepared in using autoclaved distilled water. About $100 \mathrm{~mL}$ of kaolin solution was poured in a $250 \mathrm{~mL}$ conical flask (Laboratory Consumables and Chemical Supplies Cc, Durban, South Africa) and mixed with $2 \mathrm{~mL}$ of cell-free supernatant and $3 \mathrm{~mL}$ of $1 \% \mathrm{CaCl}_{2}(w / v)$ solution. The mixture was agitated for $1 \mathrm{~min}$, poured into a $100 \mathrm{~mL}$ measuring cylinder, and allowed to stand for $5 \mathrm{~min}$ at room temperature to sediment. A crude bioflocculant was replaced with a sterile production medium for a control. The optical density (OD) of the treated solution was measured at a wavelength of $550 \mathrm{~nm}$ using a spectrophotometer (Spectro-quant, Pharo 300 Merck, Boston, MA, USA). The following equation was utilized to calculate the percentage (\%) flocculating activity.

$$
\text { Flocculating activity }(\mathrm{FA})=\left[\frac{A-B}{A}\right] \times 100 \%
$$

where $A$ is the $\mathrm{OD}$ at $550 \mathrm{~nm}$ of kaolin clay suspension and $B$ is the optical density at $550 \mathrm{~nm}$ of the treated solution.

\subsection{Identification and Purification of Fungi}

The strain with the highest promising flocculating activity against kaolin clay suspension was selected, and identified using molecular technique. The genome DNA of the yeast was extracted by a ZR Fungal/Bacterial Kit ${ }^{\mathrm{TM}}$ (Zymo Research, Catalogue No. D6005, New York, NY, USA) according to the manufacturer's instructions. Polymerase chain reaction (PCR) was employed to amplify of the fungal ribosomal RNA gene by the primers ITS1: 5'-TCCGTAGGTGAACCTGCGG-3' and ITS4: $5^{\prime}$-TCCTCCGCTTATTGATATGC- ${ }^{\prime}$, using OneTaq ${ }^{\mathrm{TM}}$ Quick Load 2x Master Mix (NEB, Catalogue No. M0486 Ipswich, MA, USA). PCR products were run on gel, followed by gel extraction using Zymoclean ${ }^{\mathrm{TM}}$ Gel DNA 
Recovery kit (Zymo Research, Catalogue No. D4001, Ipswich, MA, USA). The obtained fragments were sequenced in the forward and reverse directions on Nimagen, Brilliantdye $\mathrm{T}^{\mathrm{TM}}$ Terminator Cycle Sequencing Kit V3.1, BRD3-100/1000 and cleaned by Zymo Research, ZR-96, DNA Sequencing Clean-up Kit ${ }^{\mathrm{TM}}$, Catalogue No. D4050. The cleaned portions were analyzed by ABI PRISM ${ }^{\mathrm{TM}} 3500 x \mathrm{xl}$ Genetic Analyzer. The cleaned sequencing products were analyzed by CLC Bio Main Workbench v7.6, followed by a BLAST search using the US National Center for Biotechnology Information (NCBI) database to ascertain the closest fungal strain [21].

\subsection{Optimization of Culture Conditions for Bioflocculant Production}

Temperature, fermentation time, initial $\mathrm{pH}$, shaking speed, cations, inoculum size, and carbon and nitrogen sources are the major factors which were optimized to enhance and increase the production yield and flocculation efficiency of the selected isolate [22]. The selected isolate had the initial flocculating activity of $75 \%$ against kaolin solution.

\subsubsection{Effect of Inoculum Size on Bioflocculant Production}

To determine the optimum inoculum size for bioflocculant production, the broth culture ranging from $1 \%(v / v)(0.5 \mathrm{~mL})$ to $5 \%(v / v)(2.5 \mathrm{~mL})$ was made and inoculated into $100 \mathrm{~mL}$ conical flasks with $50 \mathrm{~mL}$ sterile production medium. The inoculated flasks were incubated at $30{ }^{\circ} \mathrm{C}$ for $72 \mathrm{~h}$ at $160 \mathrm{rpm}$. The flocculating activity was measured by mixing $3 \mathrm{~mL}$ of $1 \%(w / v)$ calcium chloride and $2 \mathrm{~mL}$ cell-free supernatant and $100 \mathrm{~mL}$ kaolin suspension $(4 \mathrm{~g} / \mathrm{L})$ added in $250 \mathrm{~mL}$ conical flask (ChemLabs, Johannesburg, South Africa). The mixture was shaken thoroughly for $1 \mathrm{~min}$, transferred into graduated measuring cylinder $(100 \mathrm{~mL})$ and allowed to stand at room temperature for 5 min for sedimentation. The clear supernatant was utilized to determine flocculating activity at $550 \mathrm{~nm}$ as described in Section 3.4. The inoculum size with the highest flocculating activity was used in all subsequent experiments [23].

\subsubsection{Effect of Carbon and Nitrogen Sources on Bioflocculant Production}

Different carbon sources such as lactose, galactose, glucose, starch, sucrose xylose, and maltose were used, replacing glucose in the original production mediums. The isolate was inoculated in the production medium and incubated at $30^{\circ} \mathrm{C}$ for $72 \mathrm{~h}$ in a shaker at $160 \mathrm{rpm}$. Flocculating activity determination was conducted after 3 days of incubation. The effect of different nitrogen sources (peptone, yeast extract, $\left(\mathrm{NH}_{4}\right)_{2} \mathrm{SO}_{4}, \mathrm{NH}_{4} \mathrm{Cl}$, and urea) on flocculating activity, were used. The equivalent amount $(1.2 \mathrm{~g} / \mathrm{L})$ of the multiple nitrogen sources (urea, yeast extract, and $\left.\left(\mathrm{NH}_{4}\right)_{2} \mathrm{SO}_{4}\right)$ (ChemLabs, Johannesburg, South Africa) used in the original medium was replaced with each nitrogen source, separately. The isolate was inoculated and incubated at $30^{\circ} \mathrm{C}, 160 \mathrm{rpm}$ for $72 \mathrm{~h} \mathrm{[20].} \mathrm{After} \mathrm{incubation,}$ the flocculating activity was measured as described previously. The carbon and nitrogen sources that showed the highest flocculating activity were used for further research.

\subsubsection{The Effect of Agitation on the Production of a Bioflocculant}

The method described by Zhang et al. [11] was followed to assess the dissimilar shaking speed effect on the flocculating activity. The assessed shaking speeds were 60 , $80,100,120,140,160$, and $180 \mathrm{rpm}$. Conical flasks $(250 \mathrm{~mL})$ with production media of $50 \mathrm{~mL}$ were inoculated with the optimum inoculum size $(v / v)$ of the bioflocculantproducing isolate and incubated at $30{ }^{\circ} \mathrm{C}$ for $72 \mathrm{~h}$ at dissimilar shaking speed ranges of 60-180 rpm. After $72 \mathrm{~h}$ of fermentation, the flocculating activity was determined for the different shaking speeds and the shaking speed that showed the highest flocculating activity was used for all the experiments followed. 


\subsubsection{Effect of Initial $\mathrm{pH}$ on Bioflocculant Production}

The initial $\mathrm{pH}$ effect on bioflocculant production was evaluated by varying $\mathrm{pH}$ of the production medium with $0.1 \mathrm{M} \mathrm{HCl}$ and $0.1 \mathrm{M} \mathrm{NaOH}$ (ChemLabs, Johannesburg, South Africa) to adjust it to $\mathrm{pH}$ values ranging from 3 to 12 . The $\mathrm{pH}$ adjustment was made before the production medium was sterilized. Thereafter, the isolate was inoculated and incubated at $30^{\circ} \mathrm{C}, 160 \mathrm{rpm}$. After $72 \mathrm{~h}$ of cultivation, the flocculating activity was measured for each $\mathrm{pH}$ value as described previously and the $\mathrm{pH}$ value with the highest flocculating activity was used in all subsequent experiments [24].

\subsubsection{Effect of Cations on Flocculating Activity}

The cations impact on the flocculating activity was evaluated using the method by Nie et al. [25]. From the basal medium, the $1 \%(w / v) \mathrm{CaCl}_{2}$ (ChemLabs, Johannesburg, South Africa) was replaced with different metal salt solutions (1\% w/v) $\left(\mathrm{LiCl}, \mathrm{FeCl}_{3}, \mathrm{NaCl}\right.$, $\mathrm{BaCl}_{2}, \mathrm{MnCl} 2, \mathrm{KCl}$, and $\mathrm{AlCl}_{3}$ ) (ChemLabs, Johannesburg, South Africa). Each of the above cation was prepared and poured into a $250 \mathrm{~mL}$ conical flask with $100 \mathrm{~mL}$ kaolin solution and $2 \mathrm{~mL}$ of cell-free supernatant, shaken for $60 \mathrm{~s}$, transferred to a $100 \mathrm{~mL}$ measuring cylinder (Laboratory Consumables and Chemical Supplies Cc, Durban, South Africa), and left to stand at room temperature for $5 \mathrm{~min}$. To prepare the control experiment, the mixture of $100 \mathrm{~mL}$ kaolin solution and cell free supernatant was made without the addition of cations. The flocculating activity was measured as described previously and the cation with the highest effect on flocculating activity was used in all subsequent tests.

\subsubsection{Effect of Cultivation Temperature on Bioflocculant Production}

The method of Xia et al. [26] was used for determination of the effect of cultivation temperature on flocculating activity. The different temperatures $(20,25,30,35,40,45,50,55$, and $60{ }^{\circ} \mathrm{C}$ ) were used for incubation after the inoculation of the isolate in the production medium for a period of $72 \mathrm{~h}$. After fermentation, the flocculating activity was measured and the temperature that showed the highest flocculating activity was used for further research.

\subsubsection{Time Course}

The method described by Okaiyeto et al. [27] was employed for the determination of fermentation time. The obtained optimum medium components and culture conditions were all used during the determination of the effect of time on flocculating activity, $\mathrm{pH}$ and microbial growth. Thus, the isolate was inoculated into the optimum autoclaved production medium and incubated under the obtained culture conditions. Sample $(2 \mathrm{~mL})$ was drawn at $12 \mathrm{~h}$ intervals for $120 \mathrm{~h}$ to evaluate the flocculating activity, $\mathrm{pH}$, and microbial growth by measuring the OD at $660 \mathrm{~nm}$.

\subsection{Extraction and Purification of a Bioflocculant}

The method by Chen et al. [28] was used during extraction and purification of the bioflocculant. After $60 \mathrm{~h}$ of fermentation, the fermented broth was centrifuged at $8000 \mathrm{rpm}$ for $15 \mathrm{~min}$ to remove cells. About 1 volume $(1000 \mathrm{~mL})$ of distilled water was added into the cell-free supernatant, mixed properly, and re-centrifuged at $8000 \mathrm{rpm}$ for $15 \mathrm{~min}$. About 2 volumes $\left(2000 \mathrm{~mL}\right.$ ) of ethanol was then added, agitated, and stored for $12 \mathrm{~h}$ at $4{ }^{\circ} \mathrm{C}$. To obtain the crude bioflocculant, after $12 \mathrm{~h}$ the formed precipitate was vacuum dried. The crude bioflocculant was then re-dissolved in distilled water $(100 \mathrm{~mL})(w / v)$. Thereafter, the mixture of butanol and chloroform $(5: 2 \mathrm{v} / \mathrm{v})(100 \mathrm{~mL})$ was added. The mixture was thoroughly shaken and left at room temperature to stand for $12 \mathrm{~h}$. The precipitate was then centrifuged at $8000 \mathrm{rpm}$ for $15 \mathrm{~min}$ and vacuum-dried to obtain a purified bioflocculant. The weight of the dried purified bioflocculant was measured and expressed in $\mathrm{g} / \mathrm{L}$. 


\subsection{Bioflocculant Surface Morphology Analysis}

Scanning electron microscopy (SEM) (SEM-Sipma-VP03-67, Zeiss, and P-Sigma, Munich, Germany), was used for the assessment of morphological structure of the purified bioflocculant. The bioflocculant was placed on the silicon-coated slide and fixed with a spin coater at $1000 \mathrm{rpm}$ for $1 \mathrm{~min}$. The surface appearance of the flocculated kaolin clay and kaolin clay particles were also investigated in the same way.

\subsection{Chemical Analysis of the Purified Bioflocculant}

\subsubsection{Fourier Transform Infrared Spectrophotometer (FT-IT) Analysis}

The FT-IR spectroscopy (Perkin Elmer System 2000, Cambridge, UK) was used to evaluate the functional groups of the purified bioflocculant. The purified bioflocculant $(3 \mathrm{mg}$ ) was subjected to FT-IR spectroscopy. The sample was run at room temperature in the wavelength ranges of $4000-400 \mathrm{~cm}^{-1}$ after being mixed with potassium bromide (KBr).

\subsubsection{X-ray Diffraction Analysis of the Bioflocculant}

A Bruker D8 Advance diffractometer (Johannesburg, Burker 2190, South Africa) equipped with $\mathrm{Cu}-\mathrm{K} \alpha$ radiation (1.5406) at $40 \mathrm{kV}, 40 \mathrm{~mA}$ was utilized to investigate the crystallinity of the bioflocculant at room temperature. The bioflocculant were put on a sample holder, and the patterns of diffraction were recorded from 0 to 80 degrees [29].

\subsection{Flocculation of a Purified Bioflocculant}

\subsubsection{Effect of Dosage Concentration on Flocculating Activity}

The method described by Makapela [30] was utilized to determine the purified bioflocculant dosage concentration effect on flocculating activity. Concentration ranges of the bioflocculant solutions were prepared in a range between 0.2 and $1.0 \mathrm{mg} / \mathrm{mL}(w / v)$. The bioflocculant solution $(2 \mathrm{~mL})$ for each concentration was mixed with the kaolin clay suspension $(100 \mathrm{~mL})$ and $3 \mathrm{~mL}$ of $1 \%(w / v) \mathrm{NaCl}$ in a conical flask $(250 \mathrm{~mL})$ and vigorously shaken. A standing graduated measuring cylinder $(100 \mathrm{~mL})$ was used to transfer the thoroughly shaken solution and was allowed to stand for $5 \mathrm{~min}$ at room temperature to sediment. As previously described, the flocculating activity of the clear supernatant was determined.

\subsubsection{Effect of Heat on Flocculating Activity}

The thermal stability of the bioflocculant was assessed within the range of $50-121^{\circ} \mathrm{C}$. To evaluate the thermal stability, $10 \mathrm{~mL}$ of the bioflocculant solution $(0.4 \mathrm{mg} / \mathrm{mL})$ was heated for $30 \mathrm{~min}$ at different temperatures. Afterwards, the heated bioflocculant solution $(2 \mathrm{~mL})$ was poured into a mixture of kaolin clay suspension $(100 \mathrm{~mL})$ and $3 \mathrm{~mL}$ of $1 \%(w / v)$ $\mathrm{NaCl}$ in a conical flask $(250 \mathrm{~mL})$. The mixture was agitated and allowed to stand for $5 \mathrm{~min}$. Thereafter, the flocculating activity was measured as described previously [31].

\subsubsection{Effect of $\mathrm{pH}$ on Flocculating Activity}

The $\mathrm{pH}$ stability of the purified bioflocculant was determined. Before the determination of flocculating activity against $\mathrm{pH}$, kaolin solution $(4 \mathrm{~g} / \mathrm{L})(100 \mathrm{~mL})$ was adjusted to $\mathrm{pH}$ range of 3-12 using $0.1 \mathrm{M} \mathrm{NaOH}$ or $0.1 \mathrm{M} \mathrm{HCL}$ (ChemLabs, Johannesburg, South Africa). Then, $2 \mathrm{~mL}$ of $0.4 \mathrm{mg} / \mathrm{mL}$ solution of a bioflocculant, $3 \mathrm{~mL}$ of $1 \% \mathrm{NaCl}(w / v)$, and kaolin solution $(100 \mathrm{~mL})$ were mixed. The flocculating capability of the bioflocculant was then calculated [26].

\subsubsection{Effect of $\mathrm{NaCl}$ Concentration on Flocculating Activity}

The method used by Maliehe et al. [23] was adopted for the evaluation of the effect of salinity of the bioflocculant. By varying the different $\mathrm{NaCl}$ concentrations in a range of 5-30 g/L in kaolin solution ( $4 \mathrm{~g} / \mathrm{L})$, the effect of salinity on bioflocculant's flocculating activity was studied. 


\subsection{Statistical Analysis}

All data were collected in triplicates with mean and standard deviation values determined where differences were considered significant at 0.05 at confidence level $(p>0.05)$ by the use of Graph Pad Prism version 6 . The significance was evaluated by variance analysis (ANOVA).

\section{Results and Discussion}

\subsection{Isolation and Identification of Fungi with Bioflocculant-Producing Potential}

The Kombucha tea SCOBY was used as the source for the isolation of the bioflocculantproducing microorganisms. Dilutions were made to obtain pure cultures and the obtained pure cultures were screened for bioflocculant production potential. Three isolated microorganisms were screened for bioflocculant production against kaolin clay suspension $(4 \mathrm{~g} / \mathrm{L})$. The isolate with the highest flocculating activity $(75 \%)$ was selected. The isolate was further identified using $16 \mathrm{~S}$ rRNA sequencing method. In the GenBank database, the isolates comparative analysis of its $16 \mathrm{~S}$ rRNA sequence showed 99\% similarities with Pichia kudriavzevii and the accession number of the isolate was MH545928.1. Therefore, the isolate was named Pichia kudriavzevii MH545928.1. P. kudriavzevii, previously known as Issatchenkia orientalis, is the teleomorph of the Candida krusei. It is abundant in the environment and commonly found in soil, on the skins of fruits, as well as in fermented beverages. Like most yeast, P. kudriavzeii is predominately used in the fermentation of wine and beer [32]. However, to the best of our knowledge, this fungus has not been reported as a bioflocculant-producer.

\subsection{Optimization of Culture Conditions for Bioflocculant Production}

Bioflocculant production is reported to be influenced by factors such as carbon and nitrogen sources, oligoelements, and operating parameters (inoculum size, temperature, $\mathrm{pH}$, aeration rate, etc.) [33]. In order to increase the bioflocculant production by P. kudriavzevii MH545928.1 and the 75\% activity, different growth factors were optimized using the one-factor-at-a-time method.

\subsubsection{Effect of Inoculum Size on Bioflocculant Production}

The literature reveals that inoculum size is important for flocculating activity of a bioflocculant and during its production. Muthudineshkumar and Anand, Ref. [34] reported that the excessive inoculum size could clump-up the microorganisms and result in the inhibition of bioflocculant production while the insufficient inoculum size might lead to a delay of growth of microbes resulting to the poor bioflocculant production. It was observed that the bioflocculant was optimally produced when the inoculum size was $1 \%(v / v)$ with the flocculating activity of $95 \%$ (Figure 1). The increase in inoculum sizes from $1 \%$ $(0.5 \mathrm{~mL})$ led to a decrease in flocculating activity. The lowest activity of $67 \%$ was observed at the inoculum size of $5 \%(2.5 \mathrm{~mL})$. A large inoculum probably made the niche of the P. kudriavzevii MH545928.1 to overlap excessively and inhibit the bioflocculant production. A bioflocculant produced by Aspergillus flavus was reported to attain the highest flocculating activity of $86.6 \%$ when $2 \%(v / v)$ inoculum size was used [35]. Therefore, each and every microorganism has its preferred inoculum size for optimal production of the bioflocculant. Thus, in all the experiments that followed, the inoculum size of $1 \%(v / v)$ was used in this study.

\subsubsection{Effect of Carbon Source on the Production of a Bioflocculant}

Carbon sources are considered as key factors during the bioflocculant production as they enhance the growth and production rate; thus, dissimilar microorganisms have varied preference for carbon sources [36]. The effect of various carbon sources on the production of a bioflocculant by P. kudriavzevii MH545928.1 was investigated and the results are depicted in Table 1. It was observed that among the studied carbon sources, glucose was the most preferred carbon source with $94.8 \%$ flocculating activity. All tested carbon sources were effective for production of the bioflocculant with more than $70 \%$ flocculating activity. The 
findings were in agreement with other studies, which stated that glucose is the most preferred carbon source for P. kudriavzevii MH545928.1 [37,38]. Glucose was then used for all subsequent experiment.

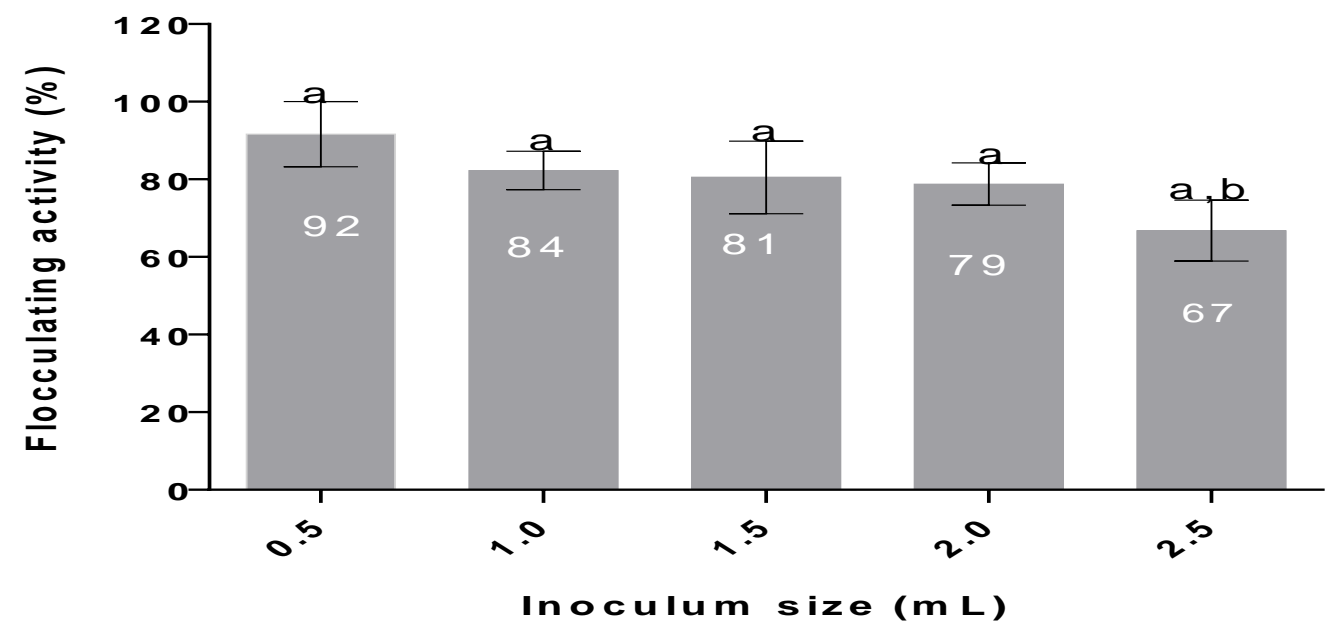

Figure 1. The effect of inoculum size on bioflocculant production. Different letters $(a, b)$ signify statistical significance at $(p<0.05)$.

Table 1. Effect carbon and nitrogen sources, speed, temperature, cation, and $\mathrm{pH}$ on flocculation.

\begin{tabular}{|c|c|c|c|c|c|c|c|c|c|c|c|}
\hline Carbon Source & FA (\%) \pm SD & Nitrogen Source & FA $(\%) \pm$ SD & Speed (rpm) & FA (\%) \pm SD & Temperature $\left({ }^{\circ} \mathrm{C}\right)$ & FA $(\%) \pm$ SD & Cations & FA $(\%) \pm$ SD & $\mathrm{pH}$ & FA $(\%) \pm$ SD \\
\hline Sucrose & $79.3 \pm 1.79^{a}$ & Casein & $78 \pm 0.41^{a}$ & 60 & $67.3 \pm 0.94^{\mathrm{a}}$ & 20 & $69.3 \pm 0.47^{\mathrm{a}}$ & $\mathrm{MnCl}^{2+}$ & $78.3 \pm 10.27^{\mathrm{a}}$ & 3 & $53.4 \pm 0.04^{\mathrm{a}}$ \\
\hline Lactose & $81.4 \pm 0.49 \mathrm{a}$ & $\left(\mathrm{NH}_{4}\right)_{2} \mathrm{SO}_{4}$ & $80 \pm 0.49 \mathrm{a}$ & 80 & $71.3 \pm 2.62 \mathrm{a}$ & 25 & $71.7 \pm 3.09 \mathrm{a}$ & $\mathrm{AlCl}^{3+}$ & $74.3 \pm 1.25 \mathrm{a}$ & 4 & $56.4 \pm 0.05 \mathrm{a}$ \\
\hline Maltose & $87.3 \pm 4.58^{\mathrm{a}}$ & Peptone & $94 \pm 0.31 \mathrm{~b}$ & 100 & $71.7 \pm 4.50^{\mathrm{a}}$ & 30 & $86 \pm 12.96^{\mathrm{a}}$ & $\mathrm{FeCl}^{3+}$ & $73.0 \pm 2.49^{a}$ & 5 & $56.7 \pm 0.17^{\mathrm{a}}$ \\
\hline Glucose & $92.2 \pm 1.85 \mathrm{ab}$ & $\mathrm{NH}_{4} \mathrm{NO}_{3}$ & $72 \pm 0.54 \mathrm{ab}$ & 120 & $95.3 \pm 2.87 \mathrm{~b}$ & 35 & $97 \pm 0.82 \mathrm{a}$ & $\mathrm{K}^{+}$ & $73.3 \pm 0.94 \mathrm{a}$ & 6 & $69.2 \pm 0.15^{a}$ \\
\hline Starch & $82.3 \pm 2.36$ ab & Yeast extract & $87 \pm 0.31$ abc & 140 & $96.0 \pm 2.05^{b}$ & 40 & $86.7 \pm 0.47^{a}$ & $\mathrm{Li}^{+}$ & $73.3 \pm 3.30^{a}$ & 7 & $91.1 \pm 0.13 \mathrm{ab}$ \\
\hline Xylose & $75.3 \pm 2.49$ a & Urea & $72 \pm 0.54 \mathrm{ab}$ & 160 & $95.3 \pm 2.87 \mathrm{~b}$ & 45 & $82.7 \pm 11.59$ a & $\mathrm{Ba}^{2+}$ & $84.0 \pm 2.05^{a}$ & 8 & $89.2 \pm 0.17 \mathrm{ab}$ \\
\hline \multirow[t]{3}{*}{ Galactose } & $81 \pm 2.16^{a b}$ & & & 180 & $76.3 \pm 3.09 \mathrm{a}$ & 50 & $78 \pm 14.97^{\mathrm{a}}$ & $\begin{array}{c}\mathrm{Na}^{+} \\
\text {Control }\end{array}$ & $\begin{array}{c}95.0 \pm 2.5 \mathrm{ab} \\
36 \pm 2.73^{\mathrm{c}}\end{array}$ & $\begin{array}{l}9 \\
10\end{array}$ & $\begin{array}{c}91.3 \pm 1.9^{\mathrm{ab}} \\
69.0 \pm 0.4^{\mathrm{a}}\end{array}$ \\
\hline & & & & & & & & & & 11 & $77.2 \pm 0.3 \mathrm{ab}$ \\
\hline & & & & & & & & & & 12 & $68.2 \pm 0.17^{a}$ \\
\hline
\end{tabular}

FA denotes flocculating activity while SD represents standard deviation. Different letters $(\mathrm{a}-\mathrm{d})$ signify statistical significance at $(p<0.05)$.

\subsubsection{Effect of Nitrogen Source on Bioflocculant Production}

With respect to the requirements for nitrogen sources, it has been found that different microorganisms prefer different nitrogen sources for their efficient growth and production of bioflocculant [39]. Peptone, yeast extract, urea, ammonium sulphate, ammonium nitrate, and casein were the nitrogen sources evaluated for their effect on bioflocculant production by P. kudriavzevii MH545928.1. Peptone was the most preferred nitrogen source with the flocculating activity of $94 \%$ (Table 1). Ammonium sulphate and urea were the least preferred nitrogen sources with the flocculating activity of $72 \%$. Therefore, peptone was used in the production of bioflocculant by P. kudriavzevii MH545928.1. These results are in accordance with the results reported by Deng et al. [38], whereby Aspergillus parasiticus optimally produced a bioflocculant when peptone was utilized as a sole nitrogen source.

\subsubsection{Effect of Agitation on the Bioflocculant Production}

Lopez-Lopez et al. [40] reported that a continuous agitation of a production medium results in an aerobic growth stimulation as it enhances solubility of oxygen. From Figure 1, it can be observed that the low shaking speeds $(60,80$, and $100 \mathrm{rpm})$ did not favor bioflocculant production by P. kudriavzevii MH545928.1. The bioflocculant production was favored by the optimum shaking speed of $140 \mathrm{rpm}$ and yielded the flocculating activity of $96 \%$. The optimum agitation provided sufficient oxygen requirement by P. kudriavzevii MH545928.1 during its growth phase and bioflocculant production [32]. The results were in close conformity with those reported by Piyo et al. [41], whereby the best flocculation was 
obtained at $160 \mathrm{rpm}$. The similarities was attributed to the same oxygen demand by the microorganisms at different growth stages [39].

\subsubsection{Effect of Cultivation Temperature on Bioflocculant Production}

Maximum enzymatic activities take place at optimum temperatures for microbial growth and bioflocculant production. Thus, the growth temperature significantly affects fungal growth, bioflocculant production, and consequently flocculating activity [42]. The effect of temperature was investigated on bioflocculant production by $P$. kudriavzevii MH545928.1 and the most effective temperatures were $30-45^{\circ} \mathrm{C}$ as shown on the Table 1. The highest flocculating activity of $97 \%$ was observed at temperature of $35^{\circ} \mathrm{C}$ while the lowest temperature $\left(20^{\circ} \mathrm{C}\right)$ resulted in the least flocculating activity $(69 \%)$. A rise in temperature above optimum tends to increase fungal growth, metabolic functions, and bioflocculant production until the point where denaturation of biomolecules, such as proteins, set in [43]. On the other hand, low temperatures may slow down the rate of metabolic processes, such as cell wall polymer synthesis, consequently leading to poor growth and metabolite production [44]. The two phenomena were observed in this study. The highest flocculating activities of bioflocculants were reported when the microorganisms were cultured at $30^{\circ} \mathrm{C}[45]$.

\subsubsection{Effect of Cations on Bioflocculant Production}

Cations have been found to either inhibit or stimulate the production of bioflocculants $[46,47]$. Mechanisms involved in stimulation are stabilization and neutralization of the residual charge of functional groups on the bioflocculant by the cations [38]. The suspension solution of metal ions results in the increase of the ionic strength because of the addition of the metal ion; thus, reducing electrostatic forces of the suspended impurities [16]. The various cations' effect on flocculating activity of the production of the bioflocculant by P. kudriavzevii MH545928.1 was studied and the results are shown Table 1. The different cations ions including monovalent $\left(\mathrm{Na}^{+}, \mathrm{K}^{+}\right.$, and $\left.\mathrm{Li}^{+}\right)$, divalent $\left(\mathrm{Mn}^{2+}\right.$ and $\left.\mathrm{Ba}^{2+}\right)$, and trivalent $\left(\mathrm{Al}^{3+}\right.$ and $\mathrm{Fe}^{3+}$ ) and the control were evaluated. The monovalent $\mathrm{NaCl}$ showed the highest flocculating activity of $95 \%$, followed by divalent $\mathrm{MnCl}_{2}$ and $\mathrm{BaCl}_{2}$ with flocculating activity of 78 and $84 \%$, respectively. Other metal ions such as $\mathrm{AlCl}_{3}, \mathrm{FeCl}_{3}$, $\mathrm{KCl}$, and $\mathrm{LiCl}$ also gave flocculating activities above $70 \%$. Thus, the bioflocculant seems to be cation dependent with the control (no cation) showing less than $40 \%$ flocculating activity. Nevertheless, Lian, [48] reported that some microorganisms do not require addition of cations for their optimum bioflocculant production. Contrary to the study findings, a bioflocculant produced by Bacillus sp. AEMREG4 was reported to show low flocculating activity of $67.7 \%$ for $\mathrm{Na}^{+}$(monovalent cation) and $\mathrm{Al}^{3+}$ (trivalent cation) showed the highest flocculating activity (83.3\%) [49]. Therefore, $\mathrm{Na}^{+}$cation was used in all subsequent experiments in this study.

\subsubsection{Effect of Initial $\mathrm{pH}$ on Bioflocculant Production}

Dissimilar microbes prefer varied $\mathrm{pH}$ ranges for the production of bioflocculants. The initial $\mathrm{pH}$ of the culture medium influences the electric charge of the microbial cells and the redox potential that can have an impact on enzymatic reactions and nutrient absorption [41]. Table 1 depicts the effect of the initial $\mathrm{pH}$ of the medium on bioflocculant production. Over the $\mathrm{pH}$ range of 3-7, the lowest flocculating activity was 53\%; within the range of $\mathrm{pH} 7-12$, the least activity $(68 \%)$ was obtained when the initial $\mathrm{pH}$ was 12 . The optimal $\mathrm{pH}$ for bioflocculant production for P. kudriavzevii $\mathrm{pH} 7$ and $\mathrm{pH} 9$, which gave the flocculating activity of $91 \%$. Therefore, $\mathrm{pH} 7$ was used for all subsequent tests as it could save the amount of alkaline and acid solutions required to adjust the $\mathrm{pH}$, consequently reducing the cost of production. These findings are in accordance with the study by [32], whereby Aspergillus flavus MCB 271 and Aspergillus niger MCBF 08 produced a bioflocculant optimally at pH 7. 


\subsubsection{Time Course on Production for Bioflocculant}

The growth curve for the microorganism according to flocculating activity, optical density $\left(\mathrm{OD}_{660 \mathrm{~nm}}\right)$, and $\mathrm{pH}$ is depicted in Figure 2. The optimal flocculation conditions that were obtained previously from the experiments were utilized for the growth curve. The yeast P. kudriavzevii MH545928.1 was examined for the production of a bioflocculant during the growth curve $(120 \mathrm{~h})$. The microbe was able to optimally produce the bioflocculant at $60 \mathrm{~h}$ of cultivation with flocculating activity of $99.1 \%$. After $60 \mathrm{~h}$ of fermentation, the flocculating activity declined constantly. It has been observed that nutrients deficiency is in direct proportion to the decline of the cell growth from the production medium of the microorganism. This explains the reason for a reduction in flocculating activity of the bioflocculant production after $60 \mathrm{~h}$. In general, the reduction may also be in correlation to the bioflocculant degrading enzyme that is produced and released; in turn, the produced bioflocculant is utilized as a source of carbon, or this depletion may be the result of autolysis. The findings were in accordance to those of Deng et al. [38], who reported that Aspergillus parasiticus produced bioflocculant with maximum flocculating activity (98.1\%) after $60 \mathrm{~h}$. This confirms that some fungi are able to produce bioflocculant with maximum flocculating activity during the early stationary phase of their cultivation. Contrary to these study findings, other studies have shown that some bioflocculants are produced at the late stationary phase of cultivation [50]. It was suggested that the decrease in the flocculation activity observed after $60 \mathrm{~h}$ could be attributed to the molecular weight decrease in the bioflocculant due to protease hydrolysis due to the decrease in $\mathrm{pH}$ [51]. A direct proportionality was also observed in the study between optical density and flocculation activity. The similarities shown by the growth and activity is an indication that the bioflocculant was not produced by autolysis of cells, rather by a biosynthesis process [52]. The $\mathrm{pH}$ of the production medium decreased from $\mathrm{pH} 7.05$ to $\mathrm{pH} 6$ during the exponential production of the bioflocculant. Thereafter, it increased from $\mathrm{pH} 6 \mathrm{up}$ to $\mathrm{pH}$ 7.0 at which it remained constant for $48 \mathrm{~h}$ during bioflocculant production and decreased to $\mathrm{pH}$ 5.5. The decrease might be attributed to organic acids secreted by $P$. kudriavzevii MH545928.1 during metabolic reactions [52]. A bioflocculant IH-7 produced by A. flavus presented similar findings to the current study where $\mathrm{pH}$ was seen to decrease from $\mathrm{pH} 7.0$ to 5.3 within $48 \mathrm{~h}$ of fermentation, then it increased insignificantly after $96 \mathrm{~h}$ to $\mathrm{pH} 5.6$ [3].

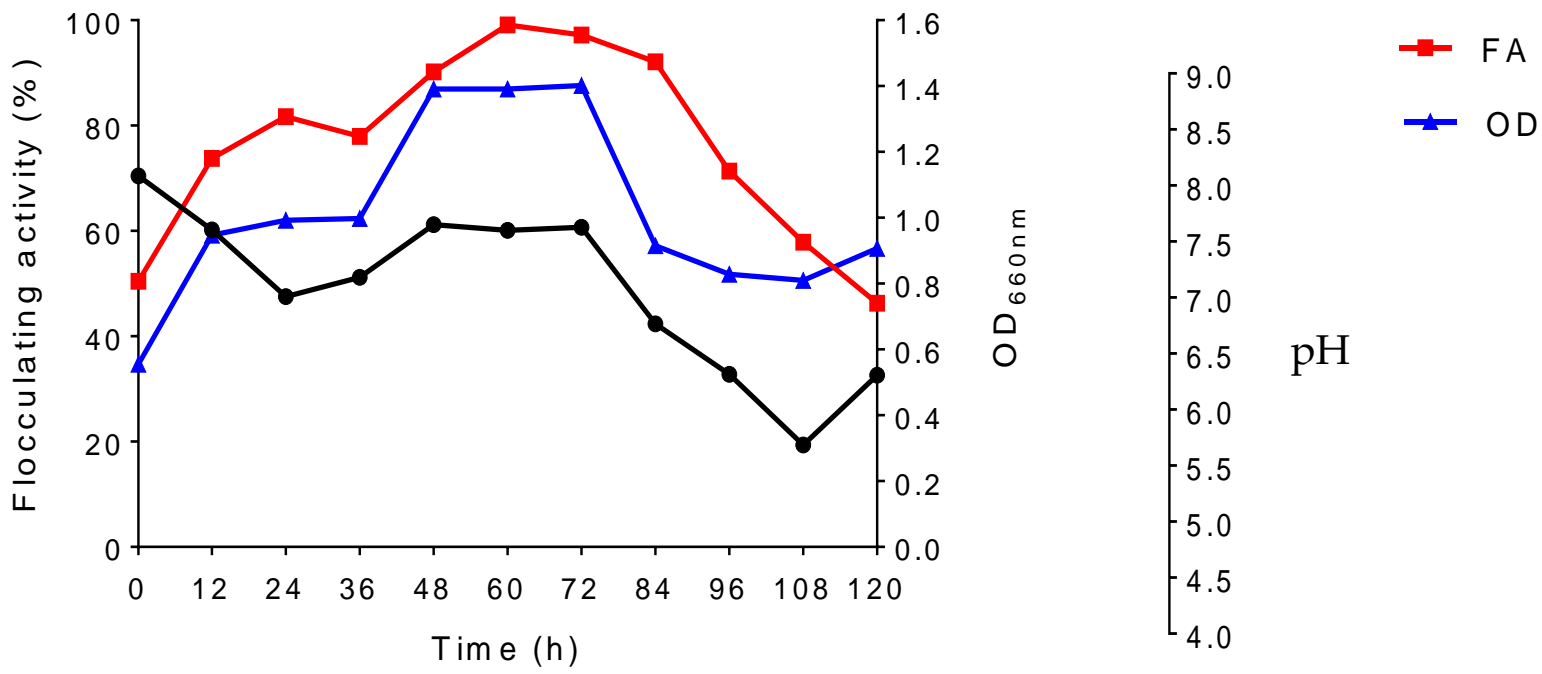

Figure 2. Effect of time course on flocculating activity, fungal growth, and $\mathrm{pH}$.

\subsection{Extraction and Purification of the Bioflocculant}

The crude bioflocculant produced by P. kudriavzevii MH545928.1 strain after extraction was $3.6 \mathrm{~g} / \mathrm{L}$. The colour substance of the bioflocculant was a milky white. The extract was 
then partially purified using a mixture of chloroform and butanol $(5: 2 v / v)$, which yielded a white powdered substance weighing about $2.836 \mathrm{~g} / \mathrm{L}$. This yield is better when compared to the one reported by Fang and Shi [53], whereby Talaromyces trachyspermus OU5 produced $1.21 \mathrm{~g} / \mathrm{L}$ of the bioflocculant. Zhang et al. [11] reported a yield of $14.8 \mathrm{~g} / \mathrm{L}$ bioflocculant from the organism Myxobacterium nannocystics sp. NU-2, which is 4 times to the yield obtained in this study. Li et al. [54] also reported that Paenibacillus elgii B69 produced a bioflocculant of $25.63 \mathrm{~g} / \mathrm{L}$ utilizing sucrose as carbon source. Low yields and high costs present significant practical application constraints in the production of bioflocculants [55]. Thus, it is suggested that in future P. kudriavzevii MH545928.1 in fungal consortia is used in order to further improve bioflocculant yield and flocculating activity.

\subsection{Characterization of the Purified Bioflocculant}

\subsubsection{Functional Groups of the Bioflocculant}

FT-IR analysis was undertaken to determine the presence of functional groups of the bioflocculant. The FT-IR spectrum revealed the presence of sharp band $\mathrm{O}-\mathrm{H}$ stretching bond at $3723 \mathrm{~cm}^{-1}$, which indicated the availability of alcohol. The hydroxyl presence in the polymer favors hydrogen bonding possibilities with one or more molecules of water, which therefore, means in an aqueous solution, the bioflocculant is highly soluble [56]. A band stretching at $3304 \mathrm{~cm}^{-1}$ indicated the presence of secondary amine. The peaks at 2996 and $2925 \mathrm{~cm}^{-1}$ were attributed to the functional group C-H of stretching vibration of sugar residues constituents. The presence of a strong vibration peak was observed at $2354 \mathrm{~cm}^{-1}$, which indicated the presence of C-O. The peaks at 2193 and $2131 \mathrm{~cm}^{-1}$ were observed, indicative of the presence of weak alkyne and strong thiocynate, respectively. Alkynes are unsaturated hydrocarbons and have been found to have a higher boiling point which could be the reason for the observed flocculating activity of the bioflocculant at higher temperatures (Figure 3) [57].

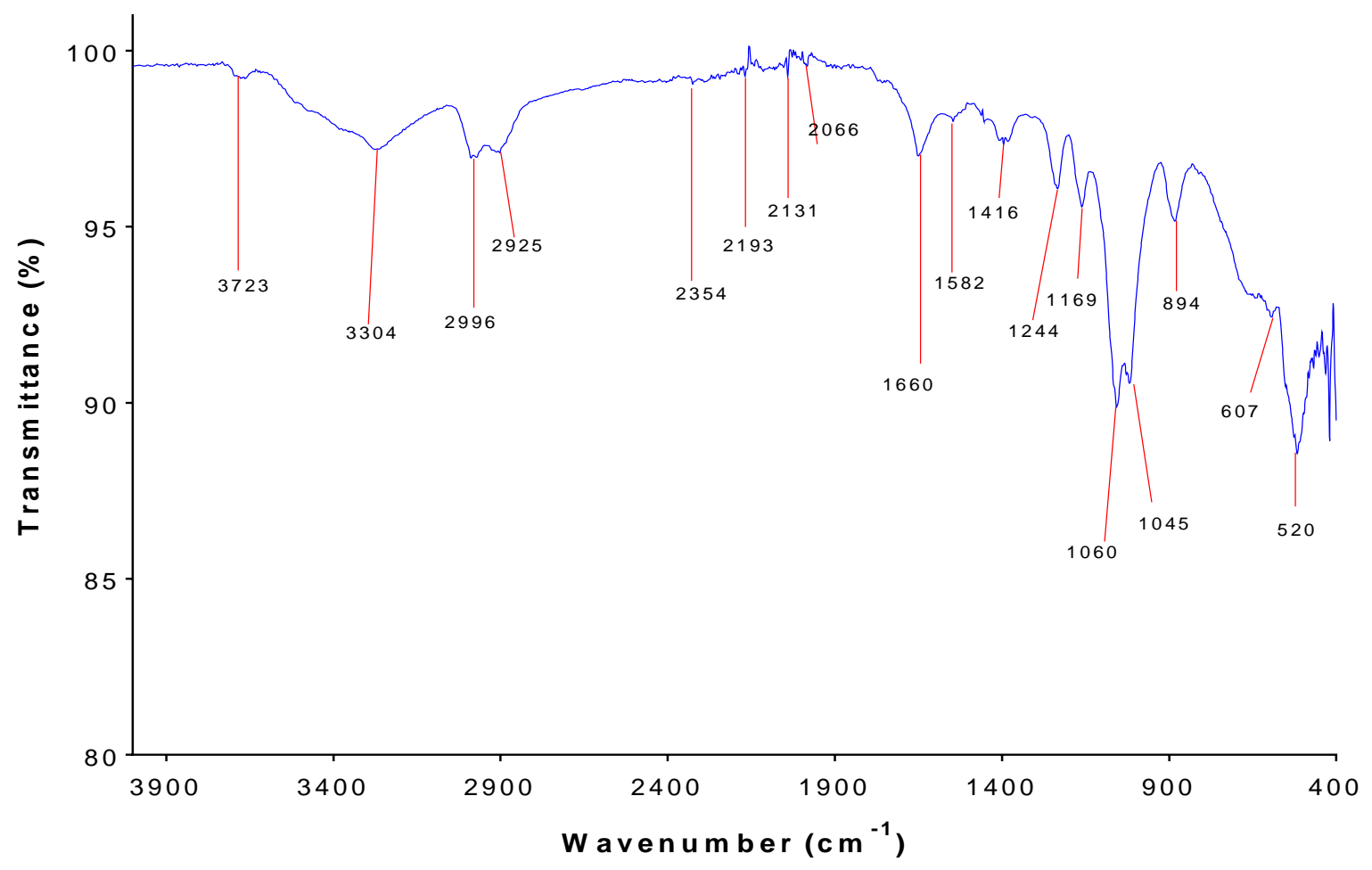

Figure 3. Infrared spectrum of the purified bioflocculant.

The thiocynate functional group shows high solubility in water $\left(177 \mathrm{~g} / 100 \mathrm{~mL}\left(0{ }^{\circ} \mathrm{C}\right)\right)$ and has a high boiling point $\left(500^{\circ} \mathrm{C}\right)$, which could be the attributor effect to the bioflocculant being able to dissolve in water and show good flocculating activity even when autoclaved 
$\left(121^{\circ} \mathrm{C}\right)$ [58]. Sharp absorption vibrations were observed at 1660 and $1582 \mathrm{~cm}^{-1}$ indicating the presence of carbonyl functional groups, which have been said to allow the spreading out of the chain due to electrostatic repulsion [59]. A strong peak at $1416 \mathrm{~cm}^{-1}$ indicated the presence of sulfonyl functional group, which has asymmetrical stretching vibrations of $\mathrm{S}=\mathrm{O}$ [3]. The presence of sugar was indicated by a small absorption peak at 1244 and $1169 \mathrm{~cm}^{-1}$, which showed C-O bonds. The aliphatic amine was revealed by the presence of strong peaks showed by the spectrum at $1060 \mathrm{~cm}^{-1}$ and $1045 \mathrm{~cm}^{-1}$. The presence of furan sugar (saccharide) was indicated by a sharp peak at $894 \mathrm{~cm}^{-1}$ and a strong peak stretching at 607 and $520 \mathrm{~cm}^{-1}$ represented a halo compound. The strong absorption peak present at 1100 and $1200 \mathrm{~cm}^{-1}$ and the functional groups (carboxyl and hydroxyl) that are available in the molecular chain of a bioflocculant are known to be general characteristics of all sugar derivatives [52]. From these observations it can be deduced that the bioflocculant consist of a polysaccharide as its main constituent. The detected functional groups were thought to be responsible in the bioflocculant's flocculation process [60]. The observed findings were also in line with the findings of other researchers for the FT-IR spectrum produced by variety of bioflocculants [61].

\subsubsection{Crystallinity of the Bioflocculant}

The X-ray pattern illustration of the bioflocculant at angle $(2 \theta)$ is depicted in Figure 4 with deep peaks observed between $10^{\circ}$ and $40^{\circ}$ angles. The strong peaks shown on the bioflocculant are very intense which could mean that the bioflocculant may have some impurities [62] The broadening of peaks in solid XRD pattern is usually due to particle size effect. Broader peaks signify smaller particle size, and this means the bioflocculant produced in this study has bigger particles as the bioflocculant does not show any broad peaks.

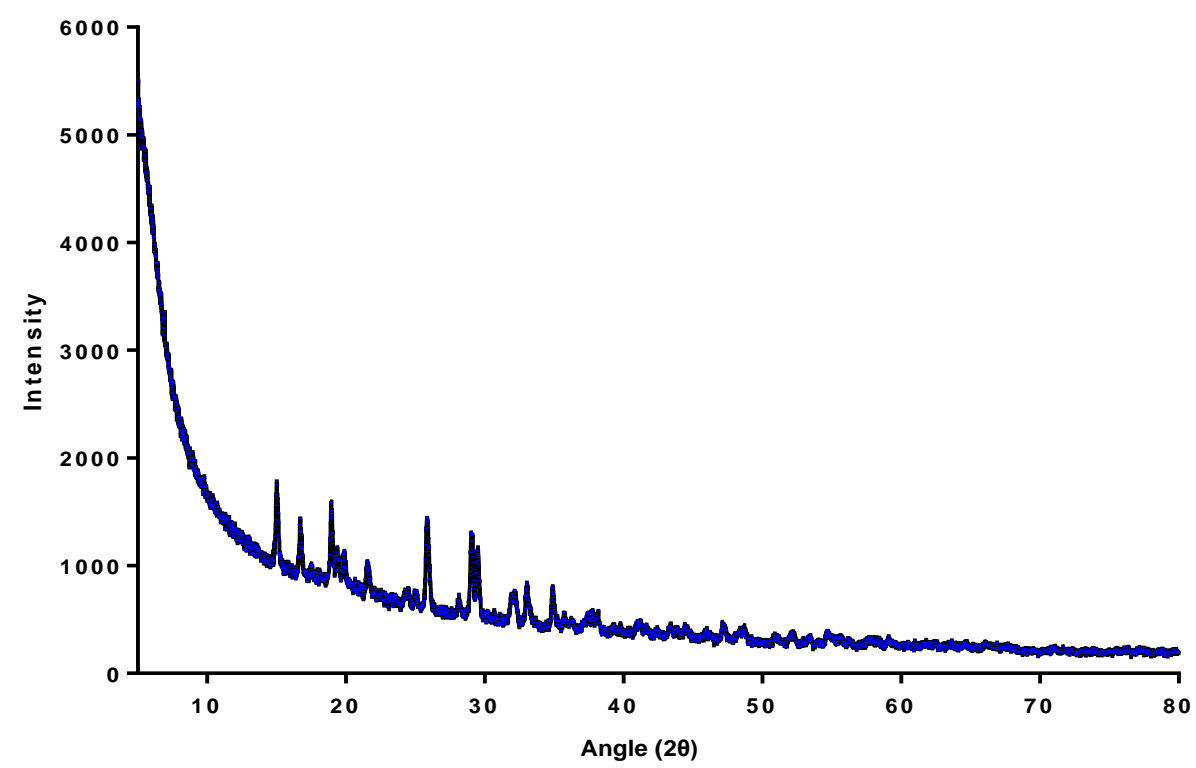

Figure 4. X-ray diffraction of the purified bioflocculant.

\subsubsection{Surface Morphology of the Bioflocculant}

In the flocculation process, the surface morphological structure of the bioflocculant is of great importance [63]. It determines the effectiveness of bioflocculants during flocculation process. Figure 5 shows images obtained using a scanning electron microscope. The image of a cumulus-like form of bioflocculant was shown (Figure 5a). The bioflocculant high-flocculating activity could be due to its configuration. The structure of the kaolin particles seemed to be fine and smooth (Figure 5b). The floc appeared clumped together after flocculation with bioflocculant (Figure 5c). The floc appeared to be interconnected 
as a result of the flocculation process, which allowed particles to be absorbed onto the bioflocculant, resulting in larger flocs.
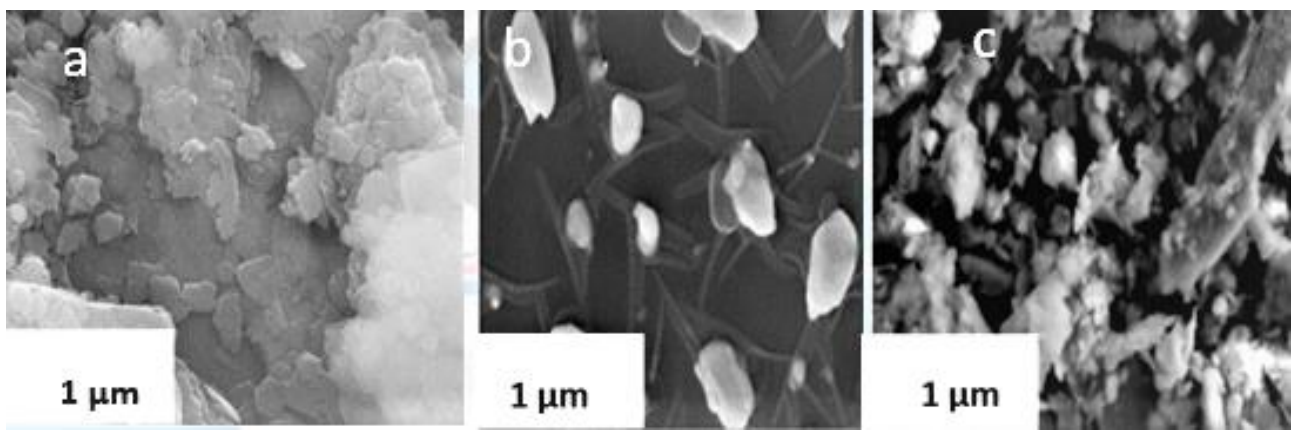

Figure 5. Scanning micrograph of the bioflocculant (a), kaolin particles (b), and flocculated kaolin particles (c).

\subsection{Flocculation Properties of the Purified Bioflocculant}

\subsubsection{Dosage Size Effect on Flocculating Activity}

In deciding bioflocculant efficiency, dosage concentration is a critical factor. Inadequate or excessive dosage can lead to inhibition in bioflocculant performance. Moreover, appropriate dosage sizes minimize expenses [64]. Thus, the effect of the dosage size was evaluated. The flocculating activity of the bioflocculant initially increased with the increase in dosage size; a subsequent decrease in activity was observed at dosage sizes higher than $0.4 \mathrm{mg} / \mathrm{mL}$. The maximum flocculating activity of $80 \%$ was obtained at $0.4 \mathrm{mg} / \mathrm{mL}$ and the lowest activity (28.3\%) was at $1 \mathrm{mg} / \mathrm{mL}$ (Table 2). Similar results were reported, whereby $0.4 \mathrm{mg} / \mathrm{mL}$ dosage size was found to have high flocculating activity (Table 3) [65]. The dosage concentration of $0.4 \mathrm{mg} / \mathrm{mL}$ was used for all the experiments that followed.

Table 2. Effect of dosage, temperature, $\mathrm{pH}$, and salinity on flocculating activity of a purified bioflocculant.

\begin{tabular}{cccccccc}
\hline $\begin{array}{c}\text { Dosage Size } \\
(\mathbf{m g} / \mathbf{m L})\end{array}$ & FA (\%) \pm SD & $\begin{array}{c}\text { Temperature } \\
(\mathbf{(} \mathbf{C})\end{array}$ & FA (\%) \pm SD & pH & FA (\%) \pm SD & Salinity (g/L) & FA (\%) \\
\hline 0.2 & $54.4 \pm 2.79^{\mathrm{a}}$ & 50 & $79.9 \pm 2.60^{\mathrm{a}}$ & 3 & $48.0 \pm 7.30^{\mathrm{a}}$ & 5 & $81.2 \pm 3.13^{\mathrm{a}}$ \\
0.4 & $80.2 \pm 2.81^{\mathrm{b}}$ & 60 & $76.8 \pm 3.57^{\mathrm{a}}$ & 4 & $48.0 \pm 4.01^{\mathrm{a}}$ & 10 & $75.0 \pm 1.24^{\mathrm{a}}$ \\
0.6 & $59.4 \pm 3.04^{\mathrm{a}}$ & 70 & $71.3 \pm 3.71^{\mathrm{a}}$ & 5 & $36.4 \pm 4.38^{\mathrm{a}}$ & 15 & $61.1 \pm 3.54^{\mathrm{ab}}$ \\
0.8 & $50.8 \pm 0.65^{\mathrm{a}}$ & 80 & $68.3 \pm 2.05^{\mathrm{a}}$ & 6 & $57.3 \pm 3.0^{\mathrm{ab}}$ & 20 & $57.0 \pm 2.86^{\mathrm{b}}$ \\
1.0 & $28.4 \pm 3.89^{\mathrm{ab}}$ & 90 & $65.5 \pm 2.48^{\mathrm{a}}$ & 7 & $67 \pm 3.37^{\mathrm{b}}$ & 25 & $50.3 \pm 5.85^{\mathrm{b}}$ \\
& & 100 & $67.57 \pm 1.82^{\mathrm{a}}$ & 8 & $69.1 \pm 1.06^{\mathrm{b}}$ & 30 & $40.4 \pm 5.59^{\mathrm{ab}}$ \\
& & 121 & $64.5 \pm 0.41^{\mathrm{a}}$ & 9 & $65.0 \pm 3.23^{\mathrm{ab}}$ & & \\
& & & & 10 & $58.0 \pm 5.57^{\mathrm{a}}$ & & \\
& & & & 11 & $53.3 \pm 1.74^{\mathrm{a}}$ & & \\
\hline
\end{tabular}

FA denotes flocculating activity, whereas SD denotes standard deviation. Different letters $(\mathrm{a}, \mathrm{b})$ denote statistical significance at $(p<0.05)$.

Table 3. Characteristics of bioflocculant from P. kudriavzevii MH545982.1 vs. bioflocculant from other fungi.

\begin{tabular}{cccccccc}
\hline $\begin{array}{c}\text { Bioflocculant } \\
\text { Producers }\end{array}$ & Dosage & FA (\%) & pH & FA (\%) & Temperature & FA (\%) & Citation \\
\hline $\begin{array}{c}\text { P. kudriavzevii } \\
\text { MH545928.1 }\end{array}$ & $0.4 \mathrm{mg} / \mathrm{mL}$ & $80.2 \%$ & 8 & $80.2 \%$ & $50{ }^{\circ} \mathrm{C}$ & $79.9 \%$ & Present study \\
Aspergillus flavus & $0.2 \mathrm{mg} / \mathrm{mL}$ & & 7 & & $35{ }^{\circ} \mathrm{C}$ & & David et al. [32] \\
Aspergillus niger & $0.4 \mathrm{mg} / \mathrm{mL}$ & & 7 & $79.0 \%$ & $40^{\circ} \mathrm{C}$ & $68.4 \%$ & Richards and Connelly [65] \\
Asperillus oryzae & $3.2 \mathrm{~g} / \mathrm{L}$ & $91.1 \%$ & 5 & $91.1 \%$ & $60^{\circ} \mathrm{C}$ & & Nie et al. [25] \\
Aspergillus niger (A18) & $5 \mathrm{~mL} / \mathrm{L}$ & $90.1 \%$ & 6 & $90.1 \%$ & $100{ }^{\circ} \mathrm{C}$ & $83 \%$ & Pu et al. [66] \\
Zryzopus sp. & $0.1 \mathrm{mg} / \mathrm{mL}$ & $85 \%$ & 5 & $83 \%$ & $30^{\circ} \mathrm{C}$ & $95 \%$ & Pu et al. [67] \\
\hline
\end{tabular}




\subsubsection{Effect of Temperature on the Bioflocculant}

The thermal stability of the bioflocculant $(0.4 \mathrm{mg} / \mathrm{mL})$ was evaluated by varying different temperatures and the results are depicted in Table 2 . The increase in temperature led to a slight decreased in the flocculating activity. The highest flocculating activity of $79 \%$ was observed at $50{ }^{\circ} \mathrm{C}$ and the lowest activity $(65 \%)$ was seen at $121{ }^{\circ} \mathrm{C}$. Pu; [66] observed similar findings where bioflocculant from Aspergillus niger (A18) retained the flocculating activity above $83 \%$ at $100{ }^{\circ} \mathrm{C}$ (Table 3). Thus, the bioflocculant is considered a thermally stable molecule. This could imply that the bioflocculant is predominately polysaccharide, which is confirmed by the identified functional groups (Figure 2) [32]. Protein rich bioflocculants have poor thermal resistance than those of polysaccharides. Thus, the slight loss of activity at high temperatures might be attributed to the denaturation of proteinous components [48]. Bioflocculants with high sugar content are reported to be heat stable and can retain more than fifty percent of their flocculating activity when exposed to high temperatures [49].

The bioflocculant produced from P. kudriavzevii was well comparable with other fungal bioflocculants from other researchers.

\subsubsection{Effect of $\mathrm{pH}$ on Flocculating Activity on the Bioflocculant}

The flocculation process is mainly influenced by $\mathrm{pH}$, which can be considered as the key factor in reaction mixture. Literature states that the alteration of $\mathrm{pH}$ may affect the bioflocculant electric status and physiognomies of suspended particles, consequently altering the flocculating activity [45]. In this study, the effect of $\mathrm{pH}$ on flocculating activity of the purified bioflocculant was assessed and the results are shown in Table 3. The bioflocculant had a promising flocculating activity at neutral, and at slightly alkaline $\mathrm{pH}$ conditions ( $\mathrm{pH} 8-9)$. The peak flocculating activity was observed at $\mathrm{pH} 8(69.1 \%)$ and the lowest $(35 \%)$ at $\mathrm{pH} 5$. The changes in the activity might be due to the changes in $\mathrm{pH}$ due to the fact that the bioflocculant and kaolin particles exhibited various electric states at different $\mathrm{pH}$ values [28]. At acidic conditions, the bio-flocculant and kaolin particles might have absorbed hydrogen ions $\left(\mathrm{H}^{+}\right)$, which weakened the formation of the bioflocculantkaolin complexes, resulting in poor flocculating activity. However, at the optimum $\mathrm{pH}$ of 8 , the hydroxide ion $\left(\mathrm{OH}^{-}\right)$absorbed promoted the formation of the complexes (bioflocculantkaolin particles), consequently leading to effective flocculating action. The promising flocculating activity of the bioflocculant at neutral and slight basic conditions indicates its ability to be used in different biotechnological applications. Contrary to these findings, Nie et al. [24], reported that a bioflocculant obtained from Aspergillus oryzae had optima flocculating activity at $\mathrm{pH} 5$ (93\%) (Table 3).

\subsubsection{Effect of Salinity on Flocculating Activity of the Bioflocculant}

High salinity tends to interfere with bioflocculants' activity. The effect of salt concentration on the flocculating activity of the bioflocculant $(0.4 \mathrm{mg} / \mathrm{mL})$ was assessed and the results are displayed in Table 3 . There was a constant decrease in flocculating activity with the increase in salt concentration. The highest activity of $81 \%$ was obtained at the lowest $\mathrm{NaCl}$ concentration of $5 \mathrm{~g} / \mathrm{L}$ while the least activity (40\%) was observed at $30 \mathrm{~g} / \mathrm{L}$. The decrease in activity could be attributed to the excessive of $\mathrm{Na}^{+}$interfering with the agglomeration between kaolin particles and the functional groups of the bioflocculants. Moreover, the bioflocculants' physical properties might have been changed due to the high $\mathrm{Na}+$ concentrations [68]. Contrary to these findings, Satyanarayana et al. [69], reported the highest flocculating activity of $94.3 \%$ by the bioflocculant at the high salinity $(25 \mathrm{~g} / \mathrm{L})$. From these findings, it can be deduced that the bioflocculant produced by P. kudriavzevii MH545928.1 can only be effectively used in environments with low $\mathrm{NaCl}$ concentrations.

\section{Conclusions}

The study showed that the fungal strain P. kudriavzevii MH545928.1 produce bioflocculant with high flocculating activity under optimum medium components and culture 
conditions. It also produces moderate bioflocculant yield when compared with other fungal strains. Its morphological structure, diverse functional groups (hydroxyl, carboxyl, amine, and thiocynates) and crystallinity are responsible for its profound flocculating activity. Moreover, the bioflocculant is effective at low dosages size $(0.4 \mathrm{mg} / \mathrm{mL})$, saline sensitive, and is thermally stable when exposed to different temperatures. The revealed properties suggested its potential applicability in industrial fields. For further studies, the bioflocculant will be applied in treatment of wastewater and dye removal.

Author Contributions: Conceptualization, A.K.B., R.V.S.R.P., and Z.G.N.; formal analysis, T.S.M.; investigation, P.H.T.; supervision, A.K.B., R.V.S.R.P., and Z.G.N.; Writing-original draft, P.H.T.; Writing-review and editing, T.S.M. All authors have read and agreed to the published version of the manuscript.

Funding: The research was sponsored by CSIR (Council for Scientific and Industrial Research) South Africa (Grant No: F171).

Institutional Review Board Statement: Not applicable.

Informed Consent Statement: Not applicable.

Data Availability Statement: Not applicable.

Acknowledgments: The authors would like to acknowledge the staff and postgraduate students (Biofloc Group) in the Department of Biochemistry and Microbiology for their outstanding support.

Conflicts of Interest: The authors declare no conflict of interest.

\section{References}

1. Ma, F.; Duan, S.; Kong, X.; Chen, X.; Yang, J.; Wang, A. Present status and development trend of studies on microbial flocculants. China Water Wastewater 2012, 28, 14-17.

2. Abraham, J.; Singh, N.; Janapal, Y.; Kumar, N.U. Optimized bioflocculant production from Fungi using response surface methodology. Int. J. Pharm. Tech. Res. 2015, 8, 230-235.

3. Aljuboori, A.H.R.; Idris, A.; Abdullah, N.; Mohamad, R. Production and characterization of a bioflocculant produced by Aspergillus flavus. Bioresour. Technol. 2013, 127, 489-493. [CrossRef] [PubMed]

4. Gao, J.; Bao, H.-Y.; Xin, M.-X.; Liu, Y.-X.; Li, Q.; Zhang, Y.-F. Characterization of a bioflocculant from a newly isolated Vagococcus sp. W31. J. Zhejiang Univ. Sci. B 2006, 7, 186-192. [CrossRef] [PubMed]

5. Sam, S.; Kucukasik, F.; Yenigun, O.; Nicolaus, B.; Oner, E.T.; Yukselen, M.A. Flocculating performances of exopolysaccharides produced by a halophilic bacterial strain cultivated on agro-industrial waste. Bioresour. Technol. 2011, 102, 1788-1794. [CrossRef]

6. $\quad \mathrm{Pu}, \mathrm{L} . ; \mathrm{Zeng}$, Y.-J.; Xu, P.; Li, F.-Z.; Zong, M.-H.; Yang, J.-G.; Lou, W.-Y. Using a novel polysaccharide BM2 produced by Bacillus megaterium strain PL8 as an efficient bioflocculant for wastewater treatment. Int. J. Biol. Macromol. 2020, 162, 374-384. [CrossRef]

7. Patil, S.V.; Patil, C.D.; Salunke, B.K.; Salunkhe, R.B.; Bathe, G.; Patil, D.M. Studies on characterization of bioflocculant exopolysaccharide of Azotobacter indicus and its potential for wastewater treatment. Appl. Biochem. Biotechnol. 2011, 163, 463-472. [CrossRef] [PubMed]

8. Pathak, M.; Sarma, H.K.; Bhattacharyya, K.G.; Subudhi, S.; Bisht, V.; Lal, B.; Devi, A. Characterization of a novel polymeric bioflocculant produced from bacterial utilization of n-hexadecane and its application in removal of heavy metals. Front. Microbiol. 2017, 8, 170. [CrossRef] [PubMed]

9. Wauer, G.; Teien, H.-C. Risk of acute toxicity for fish during aluminium application to hardwater lakes. Sci. Total Environ. 2010, 408, 4020-4025. [CrossRef]

10. Peleg, M.; Corradini, M.G. Microbial growth curves: What the models tell us and what they cannot. Crit. Rev. Food Sci. Nutr. 2011, 51, 917-945. [CrossRef]

11. Zhang, Z.-Q.; Bo, L.; Xia, S.-Q.; Wang, X.-J.; Yang, A.-M. Production and application of a novel bioflocculant by multiplemicroorganism consortia using brewery wastewater as carbon source. J. Environ. Sci. 2007, 19, 667-673. [CrossRef]

12. Ben Rebah, F.; Mnif, W.; M Siddeeg, S. Microbial flocculants as an alternative to synthetic polymers for wastewater treatment: A review. Symmetry 2018, 10, 556. [CrossRef]

13. Tlou, N.S. Characterization of Selected Microbial Species for Bioflocculant Producing Potential and Comparison with Traditional Flocculants in Industrial Waste Water Treatment; University of Zululand: Richards Bay, South Africa, 2017.

14. Sánchez-Porro, C.; Martin, S.; Mellado, E.; Ventosa, A. Diversity of moderately halophilic bacteria producing extracellular hydrolytic enzymes. J. Appl. Microbiol. 2003, 94, 295-300. [CrossRef] [PubMed]

15. La Torre, C.; Fazio, A.; Caputo, P.; Plastina, P.; Caroleo, M.C.; Cannataro, R.; Cione, E. Effects of Long-Term Storage on Radical Scavenging Properties and Phenolic Content of Kombucha from Black Tea. Molecules 2021, 26, 5474. [CrossRef] [PubMed] 
16. Watawana, M.I.; Jayawardena, N.; Gunawardhana, C.B.; Waisundara, V.Y. Health, wellness, and safety aspects of the consumption of kombucha. J. Chem. 2015, 2015, 591869. [CrossRef]

17. Sinir, G.Ö.; Tamer, C.E.; Suna, S. Kombucha tea: A promising fermented functional beverage. In Fermented Beverages; Elsevier: Amsterdam, The Netherlands, 2019; pp. 401-432.

18. Goh, C.H.; Heng, P.W.S.; Chan, L.W. Alginates as a useful natural polymer for microencapsulation and therapeutic applications. Carbohydr. Polym. 2012, 88, 1-12. [CrossRef]

19. Četojević-Simin, D.D.; Velićanski, A.S.; Cvetković, D.D.; Markov, S.L.; Mrđanović, J.Ž.; Bogdanović, V.V.; Šolajić, S.V. Bioactivity of lemon balm kombucha. Food Bioprocess Technol. 2012, 5, 1756-1765. [CrossRef]

20. Luo, Z.; Chen, L.; Chen, C.; Zhang, W.; Liu, M.; Han, Y.; Zhou, J. Production and characteristics of a bioflocculant by Klebsiella pneumoniae YZ-6 isolated from human saliva. Appl. Biochem. Biotechnol. 2014, 172, 1282-1292. [CrossRef]

21. Pryce, T.; Palladino, S.; Kay, I.; Coombs, G. Rapid identification of fungi by sequencing the ITS1 and ITS2 regions using an automated capillary electrophoresis system. Med. Mycol. 2003, 41, 369-381. [CrossRef]

22. Ray, A.; Banerjee, S.; Das, D. Microalgal bio-flocculation: Present scenario and prospects for commercialization. Environ. Sci. Pollut. Res. 2021, 28, 1-19. [CrossRef]

23. Maliehe, T.; Simonis, J.; Basson, A.; Reve, M.; Ngema, S.; Xaba, P. Production, characterisation and flocculation mechanism of bioflocculant TMT-1 from marine Bacillus pumilus JX860616. Afr. J. Biotechnol. 2016, 15, 2352-2367.

24. Salehizadeh, H.; Yan, N.; Farnood, R. Recent advances in polysaccharide bio-based flocculants. Biotechnol. Adv. 2018, 36, 92-119. [CrossRef] [PubMed]

25. Nie, M.; Yin, X.; Jia, J.; Wang, Y.; Liu, S.; Shen, Q.; Li, P.; Wang, Z. Production of a novel bioflocculant MNXY1 by Klebsiella pneumoniae strain NY1 and application in precipitation of cyanobacteria and municipal wastewater treatment. J. Appl. Microbiol. 2011, 111, 547-558. [CrossRef] [PubMed]

26. Xia, S.; Zhang, Z.; Wang, X.; Yang, A.; Chen, L.; Zhao, J.; Leonard, D.; Jaffrezic-Renault, N. Production and characterization of a bioflocculant by Proteus mirabilis TJ-1. Bioresour. Technol. 2008, 99, 6520-6527. [CrossRef] [PubMed]

27. Okaiyeto, K.; Nwodo, U.U.; Mabinya, L.V.; Okoh, A.I. Characterization of a bioflocculant produced by a consortium of Halomonas sp. Okoh and Micrococcus sp. Leo. Int. J. Environ. Res. Public Health 2013, 10, 5097-5110. [CrossRef]

28. Chen, H.; Zhong, C.; Berkhouse, H.; Zhang, Y.; Lv, Y.; Lu, W.; Yang, Y.; Zhou, J. Removal of cadmium by bioflocculant produced by Stenotrophomonas maltophilia using phenol-containing wastewater. Chemosphere 2016, 155, 163-169. [CrossRef]

29. Ntsaluba, L. Studies on Bioflocculant Production by a Consortium of Two Bacterial Species Belonging to the Methylobacterium and Actinobacterium Genera. Master's Thesis, University of Fort Hare, Faculty of Science \& Agriculture, Alice, South Africa, 2012.

30. Makapela, B. Evaluation of Bioflocculant-Producing Potential of Bacillus Pumilus Strain Isolated from Tyume River in the Eastern Cape Province of South Africa. Master's Thesis, University of Fort Hare, Alice, South Africa, 2015.

31. Manheim, D.; Nelson, Y. Settling and bioflocculation of two species of algae used in wastewater treatment and algae biomass production. Environ. Prog. Sustain. Energy 2013, 32, 946-954. [CrossRef]

32. David, O.; Oluwole, O.; Ayodele, O.; Lasisi, T. Characterisation of fungal bioflocculants and its application in water treatment. Curr. J. Appl. Sci. Technol. 2019, 34,1-9. [CrossRef]

33. Patiala, I. Studies on Polymeric Bioflocculant Producing Microorganisms. Master's Thesis, Thapar Institute of Engineering and Technology, Patiala, India, 2005.

34. Muthudineshkumar, R.; Anand, R. Anaerobic digestion of various feedstocks for second-generation biofuel production. In Advances in Eco-Fuels for a Sustainable Environment; Elsevier: Amsterdam, The Netherlands, 2019; pp. 157-185.

35. Alonso-del-Real, J.; Pérez-Torrado, R.; Querol, A.; Barrio, E. Dominance of wine Saccharomyces cerevisiae strains over S. kudriavzevii in industrial fermentation competitions is related to an acceleration of nutrient uptake and utilization. Environ. Microbiol. 2019, 21, 1627-1644. [CrossRef]

36. Dlamini, N.G. Biosynthesis of Copper Nanoparticles Using a Bioflocculant from Alcaligenis Faecalis, Characterization and Its Application. Master's Thesis, University of Zululand, Richards Bay, South Africa, 2017.

37. Dhaliwal, S.S.; Oberoi, H.S.; Sandhu, S.K.; Nanda, D.; Kumar, D.; Uppal, S.K. Enhanced ethanol production from sugarcane juice by galactose adaptation of a newly isolated thermotolerant strain of Pichia kudriavzevii. Bioresour. Technol. 2011, 102, 5968-5975. [CrossRef] [PubMed]

38. Deng, S.; Yu, G.; Ting, Y.P. Production of a bioflocculant by Aspergillus parasiticus and its application in dye removal. Colloids Surf. B Biointerfaces 2005, 44, 179-186. [CrossRef] [PubMed]

39. Mao, Z.; Xie, J.; Wang, A.; Wang, W.; Ma, D.; Liu, P. Effects of annealing temperature on the interfacial microstructure and bonding strength of $\mathrm{Cu} / \mathrm{Al}$ clad sheets produced by twin-roll casting and rolling. J. Mater. Process. Technol. 2020, 285, 116804. [CrossRef]

40. López-López, C.; Martín-Pascual, J.; Leyva-Díaz, J.C.; Martínez-Toledo, M.V.; Muñío, M.M.; Poyatos, J.M. Combined treatment of textile wastewater by coagulation-flocculation and advanced oxidation processes. Desalination Water Treat. 2016, 57, 13987-13994. [CrossRef]

41. Nontembiso, P.; Sekelwa, C.; Leonard, M.V.; Anthony, O.I. Assessment of bioflocculant production by Bacillus sp. Gilbert, a marine bacterium isolated from the bottom sediment of Algoa Bay. Mar. Drugs 2011, 9, 1232-1242. [CrossRef]

42. Rosu, C.M.; Avadanei, M.; Gherghel, D.; Mihasan, M.; Mihai, C.; Trifan, A.; Miron, A.; Vochita, G. Biodegradation and detoxification efficiency of azo-dye reactive orange 16 by Pichia kudriavzevii CR-Y103. Water Air Soil Pollut. 2018, 229, 1-18. [CrossRef] 
43. Mohammed, J.N.; Dagang, W.R.Z.W. Role of cationization in bioflocculant efficiency: A review. Environ. Process. 2019, 6, 355-376. [CrossRef]

44. More, T.; Yadav, J.S.S.; Yan, S.; Tyagi, R.D.; Surampalli, R.Y. Extracellular polymeric substances of bacteria and their potential environmental applications. J. Environ. Manag. 2014, 144, 1-25. [CrossRef]

45. Nakata, K.; Kurane, R. Production of an extracellular polysaccharide bioflocculant by Klebsiella pneumoniae. Biosci. Biotechnol. Biochem. 1999, 63, 2064-2068. [CrossRef]

46. Nguyen, N.T.; Phan, T.H.M.; Tran, T.N.; Velmurugan, B.K.; Kiefer, R. Production of novel bio-flocculants from Klebsiella variicola BF1 using cassava starch wastewater and its application. Curr. Sci. 2019, 117, 00113891. [CrossRef]

47. Ogunsade, O.O.; Bakare, M.K.; Adewale, I.O. Purification and characterization of bioflocculant produced by Bacillus amyloliquefaciens ABL 19 isolated from Adeti Stream, Ilesa, Osun State, Nigeria. Nat. Sci. 2015, 13, 54-64.

48. Lian, B.; Chen, Y.; Zhao, J.; Teng, H.H.; Zhu, L.; Yuan, S. Microbial flocculation by Bacillus mucilaginosus: Applications and mechanisms. Bioresour. Technol. 2008, 99, 4825-4831. [CrossRef]

49. Ntsangani, N.; Okaiyeto, K.; Uchechukwu, N.U.; Olaniran, A.O.; Mabinya, L.V.; Okoh, A.I. Bioflocculation potentials of a uronic acid-containing glycoprotein produced by Bacillus sp. AEMREG4 isolated from Tyhume River, South Africa. 3 Biotech 2017, 7, 78. [CrossRef] [PubMed]

50. Ngulube, T.; Gumbo, J.R.; Masindi, V.; Maity, A. An update on synthetic dyes adsorption onto clay based minerals: A state-of-art review. J. Environ. Manag. 2017, 191, 35-57. [CrossRef] [PubMed]

51. Li, Z.; Zhong, S.; Lei, H.-y.; Chen, R.-w.; Yu, Q.; Li, H.-L. Production of a novel bioflocculant by Bacillus licheniformis X14 and its application to low temperature drinking water treatment. Bioresour. Technol. 2009, 100, 3650-3656. [CrossRef]

52. Campos, V.; Fernandes, A.R.; Medeiros, T.A.; Andrade, E.L. Physicochemical characterization and evaluation of PGA bioflocculant in coagulation-flocculation and sedimentation processes. J. Environ. Chem. Eng. 2016, 4, 3753-3760. [CrossRef]

53. Fang, D.; Shi, C. Characterization and flocculability of a novel proteoglycan produced by Talaromyces trachyspermus OU5. J. Biosci. Bioeng. 2016, 121, 52-56. [CrossRef]

54. Li, N.-J.; Lan, Q.; Wu, J.-H.; Liu, J.; Zhang, X.-H.; Zhang, F.; Yu, H.-Q. Soluble microbial products from the white-rot fungus Phanerochaete chrysosporium as the bioflocculant for municipal wastewater treatment. Sci. Total Environ. 2021, 780, 146662. [CrossRef]

55. Ndejiko, J.M.; Dagang, W.R.Z.W. Flocculation Behaviour of Bioflocculant Produced from Chicken Viscera; E3S Web of Conferences; EDP Sciences: Les Ulis, France, 2019; p. 01013.

56. Pan, Y.; Shi, B.; Zhang, Y. Research on flocculation property of bioflocculant PG. a21 Ca. Mod. Appl. Sci. 2009, 3, 106-112. [CrossRef]

57. Sarkar, B.; Chakrabarti, P.; Vijaykumar, A.; Kale, V. Wastewater treatment in dairy industries-possibility of reuse. Desalination 2006, 195, 141-152. [CrossRef]

58. Wang, L.; Ma, F.; Qu, Y.; Sun, D.; Li, A.; Guo, J.; Yu, B. Characterization of a compound bioflocculant produced by mixed culture of Rhizobium radiobacter F2 and Bacillus sphaeicus F6. World J. Microbiol. Biotechnol. 2011, 27, 2559-2565. [CrossRef]

59. Xiong, Y.; Wang, Y.; Yu, Y.; Li, Q.; Wang, H.; Chen, R.; He, N. Production and characterization of a novel bioflocculant from Bacillus licheniformis. Appl. Environ. Microbiol. 2010, 76, 2778-2782. [CrossRef] [PubMed]

60. Waites, M.J.; Morgan, N.L.; Rockey, J.S.; Higton, G. Industrial Microbiology: An Introduction; John Wiley \& Sons: Hoboken, NJ, USA, 2009.

61. Li, C.; Zhang, X.; Guo, Y.; Seidi, F.; Shi, X.; Xiao, H. Naturally Occurring Exopolysaccharide Nanoparticles: Formation Process and Their Application in Glutathione Detection. ACS Appl. Mater. Interfaces 2021, 13, 19756-19767. [CrossRef] [PubMed]

62. Dlamini, N.G.; Basson, A.K.; Pullabhotla, V. Biosynthesis and characterization of copper nanoparticles using a bioflocculant extracted from alcaligenis faecalis HCB2. Adv. Sci. Eng. Med. 2019, 11, 1064-1070. [CrossRef]

63. Kavita, K.; Singh, V.K.; Mishra, A.; Jha, B. Characterisation and anti-biofilm activity of extracellular polymeric substances from Oceanobacillus iheyensis. Carbohydr. Polym. 2014, 101, 29-35. [CrossRef] [PubMed]

64. Ugbenyen, A.; Cosa, S.; Mabinya, L.; Okoh, A. Bioflocculant production by Bacillus sp. Gilbert isolated from a marine environment in South Africa. Appl. Biochem. Microbiol. 2014, 50, 49-54. [CrossRef]

65. Richardson, P.F.; Connelly, L.J. Industrial coagulants and flocculants. In Reagents in Mineral Technology; Routledge: London, UK, 2018; pp. 519-558.

66. Pu, S.; Ma, H.; Deng, D.; Xue, S.; Zhu, R.; Zhou, Y.; Xiong, X. Isolation, identification, and characterization of an Aspergillus niger bioflocculant-producing strain using potato starch wastewater as nutrilite and its application. PLoS ONE 2018, 13, e0190236. [CrossRef]

67. Pu, S.-Y.; Qin, L.-L.; Che, J.-P.; Zhang, B.-R.; Xu, M. Preparation and application of a novel bioflocculant by two strains of Rhizopus sp. using potato starch wastewater as nutrilite. Bioresour. Technol. 2014, 162, 184-191. [CrossRef] [PubMed]

68. Li, Y.; Xu, Y.; Liu, L.; Jiang, X.; Zhang, K.; Zheng, T.; Wang, H. First evidence of bioflocculant from Shinella albus with flocculation activity on harvesting of Chlorella vulgaris biomass. Bioresour. Technol. 2016, 218, 807-815. [CrossRef]

69. Satyanarayana, K.; Guimarães, J.; Wypych, F. Studies on lignocellulosic fibers of Brazil. Part I: Source, production, morphology, properties and applications. Compos. Part A Appl. Sci. Manuf. 2007, 38, 1694-1709. [CrossRef] 